\title{
Understanding the Customers' Acceptance of Pick-up Apps Over the COVID-19 Pandemic Period, Stay-at-Home Orders: An Integrated Model of UTAUT
}

\author{
Ateiya Julianita \\ Information Systems Management Department, \\ BINUS Graduate Program - Master of Information Systems Management, \\ Bina Nusantara University, \\ Jakarta, Indonesia II480 \\ atleiya.julianita@binus.ac.id \\ Viany Utami Tjhin \\ Information Systems Management Department, \\ BINUS Graduate Program - Master of Information Systems Management, \\ Bina Nusantara University, \\ Jakarta, Indonesia II 480 \\ vtjhin@binus.edu
}

\begin{abstract}
Current technological developments allow online sellers to request pick-ups via mobile apps. During the COVID-19 outbreak and with the stay-at-home orders, a survey in Indonesia showed that online transactions are increased, which led to the rise of pick-up and delivery activities. However, the pick-up order cancellation possibly happens, bad reviews appear, and apps abandonment cannot be avoided. The purpose of this study is to examine user acceptance of the pick-up apps and observe its correlation with the COVID- 19 stay-at-home orders using the Unified Theory of Acceptance and Usage of Technology (UTAUT) model with subjective norm to stay at home from the Theory of Planned Behavior (TPB) model as an additional variable. The sample was obtained from 205 users of one of the pick-up apps in Indonesia through a structured questionnaire based on a five-point Likert scale. The results showed that the stay-at-home order due to the impact of the COVID-19 pandemic affects customers' intention to use pick-up apps and performance expectancy and social influence. Then, the non-linear UTAUT variables influence each other, which is the effect of effort expectancy and social influence on performance expectancy. Finally, the main factor influencing the use behavior of pick-up apps is behavioral intention. This study can contribute to IS research on technology acceptance and provides an overview of customer behavior using the pick-up apps from a pick-up service provider viewpoint.
\end{abstract}

Keywords: Pick-up Service, Mobile App, COVID-19, Stay-at-Home Orders, UTAUT

Received I2 Oktober 202I/Accepted I3 December 202I @Author all rights reserved

\section{Introduction}

Nowadays, logistics services are used by retail companies or individuals, such as online sellers, to send goods to their customers. Along with the growth and development of technology, online sellers not only can make delivery through the drop-off points. Recently delivery service 
providers allow them to make first-mile pick-up requests and last-mile tracking through a mobile application (Agu, Ci, \& Bo, 20I5; Mohd et al., 2019) (“mobile pick-up application” will be referred to as "pick-up apps" in this paper). The couriers pick up parcels from a retail store or any pick-up location and deliver them to customer locations directly or drop them off at the delivery hubs for other processes. Courier logistics organizations tolerate rising pressure to fulfill customers' expectations and governments' requirements (Xin Wang \& Huang, 202I).

The World Health Organization (WHO) designated SARS-CoV2 infection outbreak as COVID-19 pandemic in March, 2020. In the same month the first cases of disease was reported in Indonesia (Gorbiano, 2020). By the end of March 2020, the Government of Indonesia has agreed to introduce "stay-at-home" orders or known as Large-Scale Social Restrictions (LSSR). The law defined some restrictions, including schools closure and working from home, suspension of social-cultural activities, and public gatherings and activities (Andriani, 2020).

The COVID-19 outbreak has adversely affected human lives and many sectors of the economy like manufacturing operations, logistics and supply chains (Singh, Kumar, Panchal, \& Tiwari, 2020) and introduced an unprecedented amount of uncertainty into the global economy (Stošić-Mihajlović \& Trajković, 2020). E-commerce firms in Indonesia reported that online sales volumes increased as consumers practiced social distancing during the outbreak (Oxford Business Group, 2020). It certainly affects the logistics and pick-up or delivery services (Hohtoulas, Phan, Mheen, Kwan, \& Kwan, 2020). A survey from CommerceHub reported that $69 \%$ of the customers were willing to subscribe to a delivery service following the pandemic (Berthiaume, 2020).

However, users or customers sometimes feel dissatisfied with filing a complaint or canceling orders apart from this expansion of the application and pick-up service. Pick-up order cancellation wastes drivers' efforts and reduces the availability of supplies on the transportation sector (Wang et al., 2018; Wang, Zhang, and Zhang, 2019). Adam et al. (2020) stated that reliability, price allocation, and ride comfort are the factors of customer satisfaction on Grab as one of the transportation providers. Besides, the performance of the 
apps themselves is also essential. Bad apps can raise bad reviews from customers or even badly uninstall the apps (Inukollu, Keshamon, Kang, \& Inukollu, 20I4). A survey conducted by Google showed that $25 \%$ of the installed apps were never used, and $38 \%$ were abandoned immediately after the transactions (Tiongson, 20I5). It indicated that mobile engagement becomes an essential issue (Malik, Suresh, and Sharma, 2017).

This research examines user acceptance of the pick-up apps and observe their correlation with the pandemic stay-at-home orders using UTAUT model. The model is proven to outperform the other eight theories because it presents up to $70 \%$ of variance in user acceptance (Venkatesh, Morris, Davis, \& Davis, 2003). It allows firms to approach the practical limits of their ability to explain user acceptance and use decisions within the organization (Almaiah, Al-Khasawneh, Althunibat, \& Khawatreh, 2020; Venkatesh et al., 2003).

In this study, the non-linear relationship between UTAUT variables will also be investigated to complement the linear UTAUT variable synergy (Bervell \& Umar, 2017). According to Kock (2016), there are additional advantages in applying non-linear-based models because these models tend to generate high path coefficients (Bervell \& Umar, 20I7). It will be more helpful in understanding the relationship between variables and provides a good foundation for making decision based on the results of the path relationships related to the evaluation of pick-up apps. TPB model is applied to bridge the gap in understanding the relationship between increased pick-up requests and stay-at-home orders.

\section{Literature Review}

Unified Theory of Acceptance and Usage of Technology (UTAUT)

UTAUT theory was synthesized from technology acceptance models and first used in 2003. The models include TPB, Innovation Diffusion theory (IDT), Motivational Model (MM), Technology Acceptance Model (TAM), Theory of Reasoned Action (TRA), and also the Social Cognitive Theory (SCT). UTAUT identified four key factors (Effort Expectancy, Performance Expectancy, Facilitating Conditions, and Social Influence). It also introduced four moderators which include Voluntariness, Age, Experience, and Gender, which are associated with 
predicting Behavioral Intentions to use technology especially in the organizational context called Use Behavior (Venkatesh, Thong, \& Xu, 2016). The model found that social influence, effort expectancy, and performance expectancy affect behavioral intention to use technology. In contrast, technology usage is impacted by behavioral intention and facilitating conditions.

\section{Non-linear Relationship Between UTAUT Variables}

Previous studies in user acceptance models such as TAM-I, 2, and 3 (Lai, 20I7) pointed to the critical linkages between Social Norm, Perceived Ease of Use, Perceived Usefulness, and Facilitating Conditions in explaining the purpose of acceptance. The relation of variables in the UTAUT requires investigating whether the synergy of the variables in the model becomes complete by including non-linear relationships among variables. (Bervell \& Umar, 2017).

The effect of perceived efficiency of use which is similar to effort expectancy in UTAUT; on perceived usefulness has long been debated in the TAM study (Bervell \& Umar, 2017). Supporters of this association argue that experience with new technologies engenders perceptions of how easy or not the technology will be for potential users. Therefore, individuals who experience an acceptance stage bind the relationship between using technology and performance results (Bervell \& Umar, 2017).

The influence of social customs on perceived usefulness which has similarities with social influences well as performance expectancy in UTAUT, is another relationship projected in the TAM3 model (Bervell \& Umar, 2017). Positive or negative impacts from one person to another can influence how valuable or significant the new technology is. This study will investigate the non-linear relationship between social influence and effort expectancy on performance expectancy to complement the linear UTAUT variable synergy (Bervell \& Umar, 2017). It is based on research conducted by Bervell and Umar (2017), which investigated the relationship between linear and non-linear variables of the UTAUT model in evaluating the Learning Management System (LMS). 
Theory of Planned Behavior (TPB)

In 1991, Ajzen developed the TBP theoretical model to assess a person's behavior. The model was developed from TRA theory that which in itself was developed in 1977 by Ajzen and Fishbein(Tommasetti, Singer, Troisi, \& Maione, 2018). TPB states that a person's intention to behave will be more significant when that person's attitude towards the behavior is considered beneficial, when other people who are essential to that person agree on the behavior, and when the person believes that he can perform the behavior (Callow, Callow, and Smith, 2020).

COVID-1 9 Stay-at-Home Orders as a TPB Variable

WHO conveyed several appeals to the public to reduce the spread of the SARS-CoV2 virus, including maintaining distance, wearing masks, maintaining well-ventilated rooms, avoiding crowds, cleaning hands, and covering nose and mouth coughing with tissue or inner elbow (WHO, 2020).

Due to widespread infections in Indonesia, the Government established a Public Health Emergency Status on March 31, 2020, and imposed Large-Scale Social Restrictions (LSSR) (Andriani, 2020). The LSSR is implemented in four provinces and 22 districts in Indonesia (Assegaf, 2020).

LSSR is limiting individual citizens' activities in areas that are perceived to be high risk with disease contamination to preventing the spread of the virus. This rule is in line with WHO's appeal to maintain physical distancing. Physical distancing calls have also been issued in other countries with similar terms, such as shelter-in-place in the United States, which has since changed to stay-at-home and safer-at-home (Jacobsen \& Jacobsen, 2020). Some of these different terms have in common, namely the limitation of individual mobility. As part of limiting economic activity, staying at home can play a significant role in reducing the daily COVID-19 infection curve (Camba \& Camba, 2020). The LSSR regulation itself was relaxed to become a Transitional LSSR on October I2, 2020. The start of allowing restaurants and eating places to operate and limiting 25 to 50 percent visitor capacity for recreation areas markets and malls (Enrico, 2020). 
As stated in the research background in the Introduction, the increasing number of online sales transactions led to the rise of pick-up and delivery activities. Naturally, the use of pickup apps has coincided with the COVID-19 phenomenon and the enactment of LSSR or stayat-home orders. To date, although extensive research has been carried out on factors thought to influence use behavior, no study has thoroughly investigated the use behavior on pick-up apps of the users with their new habitual patterns caused by the pandemic. This paper intends to bridge the gap in understanding the relationship between increased pick-up requests and stay-at-home calls using the subjective norm variable from the TPB model.

TPB has been applied in conducting research on COVID-19, including research on individual behavior and intentions regarding stay-at-home appeal (Callow et al., 2020; Smith \& Branscum, 2020). A study by Callow et al. (2020) stated that subjective customs, as one of the TPB variables, significantly affects an individual's intention to be socially isolated. Ajzen (1989) uses subjective norm expressions to show perceptions of social pressure that can influence people's behavior. In overall, subjective norms play an essential role in forming people's behavioral intentions with positive or negative influences that encourage each individual to take and avoid specific actions (Tommasetti et al., 2018).

The proposed conceptual model is shown in Figure I with the subjective norm to stay at home variable from the TPB model as an extra variable in UTAUT model.

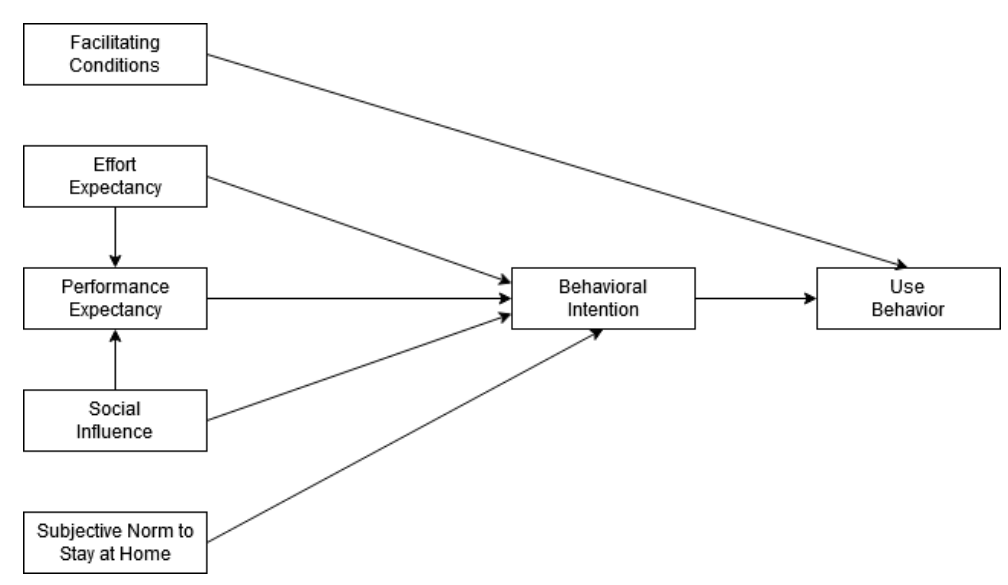

Figure I. The Conceptual Model for Customer Acceptance 
The UTAUT variables applied in this study are only the main variables: Social Influence, Effort Expectancy, Facilitating Conditions, Performance Expectancy, Behavioral Intention, and Use behavior. In addition, the antecedent variable of Behavioral Intention and Use Behavior, operationalized, refers to the TPB model: Subjective Norm. The Subjective Norm variable is considered an antecedent of user acceptance towards pick-up apps, showing a relationship with the stay-at-home guidelines during the pandemic. Subjective norms in the current stayat-home situation include the opinions of closest people, like friends and family, which influence a person's intention to stay at home, or in other words, the people most relative to the individual want him to stay at home (Callow, Callow, and Smith, 2020). It is in line with conditions in Indonesia related to the PSBB regulation, which requires people to stay at home as much as possible.

The hypotheses used in this study were built based on an amalgamation of UTAUT model based on linear as well as non-linear relationships with the TPB model related to the stay-athome guidelines during the pandemic. This concept is approached to build the hypotheses as follows:

HI: The customer's behavioral intentions can be influenced by performance expectancy in $a$ significant and positive way

H2: Social influence positively influences on customers' behavioral intentions to use pick-up apps

H3: Effort expectancy positively impact on customers' behavioral intent to use pick-up apps

H4: Facilitating conditions will have a significant positive influence on customers' pick-up apps use behavior

H5: Effort expectancy is expected to significantly impact performance expectancy in a positive manner

H6: Social influence will positively influence on performance expectancy in a significant way.

H7: Subjective norm to stay at home will have a significant positive influence on customers' behavioral intention to use pick-up apps

H8: Customers' behavioral intention will significantly influence on their pick-up apps use behavior in a positive way 


\section{Method}

Study Design

This study used an evaluative research method with a quantitative approach method. Evaluative research is a systematic process in which the activity collects and analyzes data on the quality as well as effectiveness, benefits of programs, practices or products. Unlike other types of research that aim to establish novel knowledge or comprehension, evaluative research emphases on formulating decisions about products, programs, and procedures (Gay, Mills, \& Airasian, 20I2). This study uses the Structural Equation Modeling-Partial Least Squares (SEM-PLS) method for data analysis. This method is a type of component or variance-based SEM analysis. SEM permits researchers to comprise unobservable variables that are measured indirectly by indicator variables. According to Chin (1998), this method also facilitates measurement errors in the observed variables (Hair, Hult, Ringle, \& Sarstedt, 2016).

\section{Survey Participants}

An online survey of 20 questions was applied to gather data. Bina Nusantara University approved the survey. The participants were users of one of the pick-up apps in Indonesia. The survey included questions about: social influence, performance expectancy, effort expectancy, facilitating conditions, the subjective norm to stay at home, use behavior, and behavioral intention. The participants were also asked about demographic information, such as age, sex, educational level, employment status, and application usage history. The participation in this survey was completely voluntary.

Two hundred and five individuals finished the survey which was a structured questionnaire designed on a five-point Likert scale. The analysis was carried out on the survey results collected from 205 respondents, which showed that most respondents were women (67\%). Most respondents were between 21 to 30 years old (42.2\%), followed by 31 - to 40 -year-olds (38.8\%). More than $50 \%$ of the respondents have completed a bachelor's degree $(54.4 \%)$. Almost all respondents have used the app more than once (92.2\%). 
Measurement

Reliability Test

The coefficient of Composite Reliability (CR) and Cronbach's Alpha were applied to evaluate reliability of the outcomes. Reliability measures the reliability of a study, namely the extent to which the measurement of a test remains consistent after repeated tests on research subjects. Hair et al. (2019) recommends that Cronbach's Alpha and CR scores be above 0.7 and not more than 0.95 . A higher value generally indicates a higher level of reliability. If Cronbach's Alpha or CR value is greater than 0.95 , it means that the item is redundant, thereby reducing construct validity.

\section{Validity Test}

Two stage testing was applied to determine the validity of this study. The tests include Convergent Validity test as well as the Discriminant Validity test. The former test is the degree to which variable come together to clarify the variance of the items (Hair et al., 2019). The Average Variance Extracted (AVE) was applied in assessing convergent validity. Each indicator's weight or loading value in a construct is squared, then the average value is calculated. An acceptable AVE is 0.50 or more, which is an indication that the construct explains at least 50 percent of the variance of the items.

Discriminant validity assesses the extent to which different concepts are statistically different (Tarhini, El-Masri, Ali, \& Serrano, 2016), or in other words, various variables do not correlate. To evaluate discriminant validity used the square root value of AVE measurement, which value must be greater than other correlations (Khechine \& Augier, 2019).

\section{Path Coefficient}

After the assessment of the measurement model has been completed, the next step in evaluating the results of the SEM-PLS is to assess the structural model. In the standard assessment criteria, the measurement uses statistical significance and relevance from the path coefficient (Hair et al., 2019). The path coefficient is used in assessing the relationship between variables from the designed model. In the testing in this study, the bootstrapping method was used with 5,000 sub samples. 


\section{Coefficient of Determination}

The coefficient of determination or $\mathrm{R}^{2}$ is used to show how far the model can explain the variance of the dependent variable. Hair et al. (2019) recommends an $\mathrm{R}^{2}$ of 0.5 or more.

\section{Hypotheses Test}

Hypotheses testing was conducted to test the relationship between the independent variable and the dependent variable. In this test, the bootstrapping method was carried out. The significance level $(\alpha)$ used is 0.05 , where this value is used as the $p$-value limit. So in this study, a hypothesis is said to be accepted if the $p$-value has a value less than or equal to 0.05 . The relationship between variables is said to be significant if the t-statistic is more than or equal to 1.96 .

\section{Result}

\section{Reliability, Convergent and Discriminant Validity}

Reliability and validity tests were carried out using the Smart-PLS software. In testing the reliability, this study made use of Cronbach's Alpha and CR coefficients. Hair et al. (2019) suggested that Cronbach's Alpha and CR are better at scores above 0.7 and not more than 0.95. As visualized in Table I the value of two coefficients for all measurement instruments was satisfying because they exceed 0.7 .

Table I

Cronbach's Alpha and Composite Reliability

\begin{tabular}{lll}
\hline Variable & $\alpha$ & $\mathrm{CR}$ \\
\hline Behavioral intention & 0.908 & 0.942 \\
\hline Effort expectancy & 0.903 & 0.94 \\
\hline Facilitating conditions & 0.835 & 0.901 \\
\hline Performance expectancy & $0.85 \mathrm{I}$ & $0.9 \mathrm{I}$ \\
\hline Social influence & $0.83 \mathrm{I}$ & 0.888 \\
\hline Subjective norm to stay at home & 0.813 & 0.914 \\
\hline Use behavior & 0.724 & 0.878
\end{tabular}

Note: $\alpha$ : Cronbach's alpha; CR: Composite reliability 
For the convergent validity test, the AVE measurement was used. Table 2 showed the AVE results for each variable more than 0.5 as Hair et al. (2019) recommended. Discriminant validity is measured by the value of the square root of AVE. Discriminant validity assesses the extent to which different concept measures differ statistically (Tarhini et al., 2016). The square root value of AVE must be greater than other correlations (Khechine \& Augier, 2019) and can be confirmed in Table 2.

Table 2

Convergent and Discriminant Validity for Latent Variables

\begin{tabular}{llllllll}
\hline $\begin{array}{l}\text { Variable } \\
\text { AVE }\end{array}$ & $\begin{array}{l}\text { Behavioral } \\
\text { intention }\end{array}$ & $\begin{array}{l}\text { Effort } \\
\text { expectancy }\end{array}$ & $\begin{array}{l}\text { Facilitating } \\
\text { conditions }\end{array}$ & $\begin{array}{l}\text { Performance } \\
\text { expectancy }\end{array}$ & $\begin{array}{l}\text { Social } \\
\text { influence }\end{array}$ & $\begin{array}{l}\text { Subjective Use } \\
\text { norm to } \\
\text { stay at } \\
\text { home }\end{array}$ \\
\hline $\begin{array}{l}\text { Behavioral } \\
\text { intention }\end{array}$ & 0.845 & $\mathbf{0 . 9 1 9}$ & & & \\
\hline $\begin{array}{l}\text { Effort } \\
\text { expectancy }\end{array}$ & 0.838 & 0.55 & $\mathbf{0 . 9 1 6}$ & & & \\
\hline $\begin{array}{l}\text { Facilitating } \\
\text { conditions }\end{array}$ & 0.753 & 0.575 & 0.605 & $\mathbf{0 . 8 6 8}$ & & \\
\hline $\begin{array}{l}\text { Performance } \\
\text { expectancy }\end{array}$ & 0.771 & 0.626 & 0.682 & 0.642 & $\mathbf{0 . 8 7 8}$ & & \\
\hline $\begin{array}{l}\text { Social } \\
\text { influence }\end{array}$ & 0.665 & 0.596 & 0.679 & 0.593 & 0.654 & $\mathbf{0 . 8 1 5}$ & \\
\hline $\begin{array}{l}\text { Subjective } \\
\text { norm to stay } \\
\text { at home }\end{array}$ & 0.841 & 0.522 & 0.348 & 0.455 & 0.434 & 0.418 & $\mathbf{0 . 9 1 7}$ \\
\hline $\begin{array}{l}\text { Use } \\
\text { behavior }\end{array}$ & 0.783 & 0.83 & 0.586 & 0.645 & 0.649 & 0.653 & 0.506 \\
\hline
\end{tabular}

Note: Diagonal elements: $\sqrt{ }$ AVE

\section{Hypotheses Test}

Table 3 shows the results of testing the hypotheses in this study. Measurements are made based on path coefficient $(\beta), t$-values, and $p$-values. 
Table 3

Hypotheses Result

\begin{tabular}{lllll}
\hline Hypotheses & $\beta$ & t-values & P-values & Result \\
\hline HI: Performance expectancy $\rightarrow$ & 0.293 & 3.045 & 0.003 & $\mathrm{~S}$ \\
Behavioral intention & & & & \\
\hline H2: Effort expectancy $\rightarrow$ Behavioral & $0.1 \mathrm{I}$ & $\mathrm{I} .013$ & 0.312 & $\mathrm{NS}$ \\
intention & & & & \\
\hline H3: Social influence $\rightarrow$ Behavioral & 0.219 & 2.456 & 0.015 & $\mathrm{~S}$ \\
intention & & & & \\
\hline H4: Facilitating conditions $\rightarrow$ Use & $0.25 \mathrm{I}$ & 4.28 & 0.00 & $\mathrm{~S}$ \\
behavior & & & & \\
\hline H5: Effort expectancy $\rightarrow$ Performance & 0.442 & 5.069 & 0.00 & $\mathrm{~S}$ \\
expectancy & & & & \\
\hline H6: Social influence $\rightarrow$ Performance & 0.354 & 4.394 & 0.00 & $\mathrm{~S}$ \\
expectancy & & & & \\
\hline H7: Subjective norm to stay at home $\rightarrow$ & 0.265 & 4.047 & 0.00 & $\mathrm{~S}$ \\
Behavioral intention & & & & \\
\hline H8: Behavioral intention $\rightarrow$ Use & 0.686 & $13.27 \mathrm{I}$ & 0.00 & $\mathrm{~S}$ \\
behavior & & & & \\
\hline
\end{tabular}

Note: S: Supported; NS: Not supported; *NS p>0.0I

Another assessment used the coefficient of determination or $\mathrm{R}^{2}$ to show how far the model can explain the variance of the dependent variable. Table 4 shows the variance of performance expectancy, behavioral intention, and use behavior with values exceeding 0.5 , which were quite satisfying (Hair et al., 2019).

Table 4

Coefficient of Determination

\begin{tabular}{ll}
\hline Variable & $\mathrm{R}^{2}$ \\
\hline Performance expectancy & 0.533 \\
\hline Behavioral intention & 0.512 \\
\hline Use behavior & 0.73 \\
\hline
\end{tabular}

Note: $R^{2}$ : Coefficient of determination 


\section{Discussion}

Performance expectancy was found to have a positive influence on behavioral intention ( $\beta=$ 0.293, $t=3.045, p<0.01)$, as well as social influence $(\beta=0.219, t=2.456, p<0.05)$. It is consistent with previous research (Alrawashdeh \& Al-Mahadeen, 20I3; Cokins et al., 2020; Jaradat \& Banikhaled, 20I3; Le, Ngo, Trinh, \& Nguyen, 2020; Park \& Lee, 202I; Tarhini et al., 2016; Venkatesh et al., 2003). This study found that customers' intention to use pick-up apps depends on customers' usability and social leverage assessment. Effort expectancy apparently had no influence on behavioral intention $(\beta=0.11, t=1.013, p>0.01)$. This finding is similar to several studies (Cokins et al., 2020; Khechine \& Augier, 2019; Tarhini et al., 20I6), although it is inconsistent with the previous study by Venkatesh et al. (2003). It means that customers' intention to use pick-up apps was not affected by the effort they expect to make.

The effect of effort expectancy was quite significant on performance expectancy $(\beta=0.442, t$ $=5.069, \mathrm{p}<0.0 \mathrm{I})$. The findings regarding non-linear relationships between UTAUT variables align with research conducted by Bervell and Umar (2017). It means that customers rely on the amount of effort they expected to put in before finally assessing the utility of pick-up apps. Another finding on the non-linear variable relationship is that social influence affected performance expectancy $(\beta=0.354, t=4.394, p<0.01)$. It turned out to be inconsistent with research conducted by Bervell and Umar (2017). This interesting finding suggests that social influence influenced customers before finally assessing the usability of pick-up apps.

Subjective norms to stay at home was found to have a positive influence on behavioral intention $(\beta=0.265, t=4.047, p<0.01)$. Callow, Callow, and Smith (2020) stated that subjective norms have a big effect on a person's intention to be socially isolated, which is in line with this finding. The influence of people around staying at home during the COVID-I9 pandemic affected a person's intention to use app-based online pick-up services.

Use behavior was most significantly influenced by behavioral intention $(\beta=0.686, t=13.27 \mathrm{I}$, $P<0.0 \mathrm{I})$. Besides, facilitating conditions had a positive influence on use behavior $(\beta=0.25 \mathrm{I}$, $t=4.28, p<0.01)$. It is in line with previous studies, which also stated that use behavior is influenced by behavioral intention and facilitating conditions (Bervell \& Umar, 20I7; Musyaffi, 
Agustin, Sari, \& Respati, 202I; Tarhini et al., 2016; Venkatesh et al., 2003). These findings can be interpreted that when a customer used pick-up apps, intention to use the apps was very influential, followed by facilitating conditions (such as information and guidance provided by customer service or drivers).

\section{Conclusion}

In this study regarding customer acceptance of pick-up apps, the following findings can be concluded. First, customers' intention to use pick-up apps is influenced by performance expectancy, social influence, and subjective norms to stay at home. The interesting finding in this study confirms that the stay-at-home order due to the impact of the COVID-I9 pandemic has affected customer's intention to use pick-up apps. Then, the non-linear UTAUT variables influence each other, which is the effect of effort expectancy and social influence on performance expectancy. Finally, the main factor influencing the use behavior of pick-up apps is behavioral intention. Overall, the results showed that pick-up apps are well accepted, especially in Indonesia.

This study provides an overview of customer behavior using the pick-up apps from a pick-up service provider viewpoint. This insight is essential considering the increasing demand for this pick-up service. Another perspective is the subjective norms to stay at home variable as a UTAUT extension can contribute to IS research on technology acceptance. The limitation of this study is the limited scope of the survey, so that the sample data size is relatively small. In addition, data were obtained through questionnaires filled out by respondents. Retrieval of data using the questionnaire method caused the respondents' views on the pick-up apps to be limited to the statements given only. For further research, the scope of the study can be widened by enlarging the sample. In addition, this study has been carried out according to quantitative research approach, however, similar studies in the future can use a mixed-method approach to reinforce the findings.

\section{References}

Adam, M., Kee, D. M. H., Junaina, I., Fadhilah, N., Uwais, N., Al Rashidi, F., ... Pandey, R. (2020). The Influence of Customer Satisfaction on Grab Services in Malaysia. International Journal of Tourism and Hospitality in Asia Pacific, 3(2), 26-37. 
https://doi.org//0.32535/ijthap.v3i2.820.

Agu, MN, Ci, N., \& Bo, O. (20I5). Enhancing Courier Service with the Development of an Interactive Mobile App in Android Platform. IOSR Journal of Mobile Computing \& Application, 2(2), 2394-42. https://doi.org//0.9790/0050-022566I.

Almaiah, M. A., Al-Khasawneh, A., Althunibat, A., \& Khawatreh, S. (2020). Mobile Government Adoption Model Based on Combining GAM and UTAUT to Explain Factors According to Adoption of Mobile Government Services. International Journal of Interactive Mobile Technologies, I4(3), 199-225. https://doi.org//0.399//ijim.v|4i03.II 264.

Alrawashdeh, T. A., \& Al-Mahadeen, B. M. (20I3). Extended UTAUT to Examine the Acceptance of Web Based Training System by Public Sector. International Journal of Interactive Mobile Technologies (IIIM), 7(I), 4. https://doi.org/I0.399I/ijim.v7il.2044.

Andriani, H. (2020). Effectiveness of Large-Scale Social Restrictions (PSBB) toward the New Normal Era during COVID-19 Outbreak: a Mini Policy Review. Journal of Indonesian Health Policy and Administration, 5(2), 6I-65. https://doi.org/I0.7454/ihpa.v5i2.400 I.

Assegaf, F. (2020). Indonesia fortunate to choose social distancing over lockdown Jokowi. Retrieved from Antara News website: https://en.antaranews.com/news/I47975/indonesia-fortunate-to-choose-socialdistancing-over-lockdown-jokowi.

Berthiaume, D. (2020). Survey COVID-19 will permanently shift online shopping habits. Retrieved April 18, 2020, from Chain Store Age website: https://chainstoreage.com/survey-covid-19-will-permanently-shift-online-shopping-habits

Bervell, B., \& Umar, I. N. (20I7). Validation of the UTAUT model: Re-considering non-linear relationships of exogenous variables in higher education technology acceptance research. Eurasia Journal of Mathematics, Science and Technology Education, 13(10), 647I-6490. https://doi.org/I0.I2973/ejmste/78076.

Callow, M. A., Callow, D. D., \& Smith, C. (2020). Older adults' intention to socially isolate once covid-19 stay-at-home orders are replaced with "safer-at-home" public health advisories: a survey of respondents in Maryland. Journal of Applied Gerontology, 39(II), I I75-I I83. https://doi.org/I0.1 I77/0733464820944704.

Camba, A. C., \& Camba, A. L. (2020). The Effects of restrictions in economic activity on the spread of covid- 19 in the philippines: Insights from Apple and Google mobility indicators. Journal of Asian Finance, Economics and Business, 7(12), II5- 121 . https://doi.org/I0.13 I06/JAFEB.2020.VOL7.NOI2.II5.

Cokins, G., Oncioiu, I., Türkes, M. C., Topor, D. I., Capusneanu, S., Pastiu, C. A., ... Solovastru, A. N. (2020). Intention to use accounting platforms in Romania: A quantitative study on sustainability and social influence. Sustainability (Switzerland), 12 (15). https://doi.org//0.3390/sul2I56I27. 
Enrico, B. (2020). DKI Jakarta returns back to transition large-scale social distancing Indonesia ICLG. Retrieved from iclg.com website: https://iclg.com/briefing//4796-dki-jakartareturns-back-to-transition-large-scale-social-distancing.

Gay, L. R., Mills, G. E., \& Airasian, P. W. (20I2). Educational research, competencies for analysis and applications ( 1 Oth ed.). Pearson.

Gorbiano, M. I. (2020). Breaking: Jokowi announces Indonesia's first two confirmed COVID19 cases. The Jakarta Post (Online). Retrieved from https://www.thejakartapost.com/news/2020/03/02/breaking-jokowi-announcesindonesias-first-two-confirmed-covid-19-cases.html.

Hair, J. F., Hult, G. T. M., Ringle, C. M., \& Sarstedt, M. (2016). A primer on partial least squares structural equation modeling (PLS-SEM) (2nd ed.).

Hair, J. F., Risher, J. J., Sarstedt, M., \& Ringle, C. M. (2019). When to use and how to report the results of PLS-SEM. European Business Review, 3I(I), 2-24. https://doi.org/I0.I I08/EBR-I I-2018-0203.

Hohtoulas, P., Phan, A. T., Mheen, P. van de, Kwan, E., \& Kwan, E. (2020). Consumer insights survey 2020 - an indonesian perspective: before and after the covid-19 outbreak. 2. Retrieved from https://www.pwc.com/id/en/consumer-industrial-products-services/indonesia-gcis2020-placemat.pdf

Inukollu, V. N., Keshamon, D. D., Kang, T., \& Inukollu, M. (20I4). Factors influencing quality of mobile apps: role of mobile app development life cycle. International Journal of Software Engineering \& Applications, 5(5), 15-34. https://doi.org// 0.5 I 2 I/ijsea.20 I 4.5502.

Jacobsen, G. D., \& Jacobsen, K. H. (2020). Statewide COVID-I9 stay-at-home orders and population mobility in the United States. World Medical and Health Policy, I-I0. https://doi.org//0.1002/wmh3.350.

Jaradat, M.-I. R., \& Banikhaled, M. (20I3). Undergraduate students adoption of website-service quality by applying the unified theory of acceptance and use of technology (UTAUT) in Jordan. International Journal of Interactive Mobile Technologies (IIIM), 7(3), 22. https://doi.org// 0.399//ijim.v7i3.2482.

Khechine, H., \& Augier, M. (2019). Adoption of a social learning platform in higher education: an extended utaut model implementation. Proceedings of the 52nd Hawaii International Conference on System Sciences, 53-62. https://doi.org/ 10.2425 I/hicss.2019.008.

Lai, P. (2017). The literature review of technology adoption models and theories for the novelty technology. Journal of Information Systems and Technology Management, I4(I), 21 38. https://doi.org/I0.430I/s I807-17752017000100002.

Le, H. B. H., Ngo, C. T., Trinh, T. T. H., \& Nguyen, T. T. P. (2020). Factor affecting customers' decision to use mobile banking service: $A$ case of thanh hoa province, Vietnam. Journal of Asian Finance, Economics and Business, 7(2), 205-212. 
https://doi.org//0.13106/jafeb.2020.vol7.no2.205.

Malik, A., Suresh, S., \& Sharma, S. (2017). Factors influencing consumers' attitude towards adoption and continuous use of mobile applications: A conceptual model. Procedia Computer Science, 122, 106-113. https://doi.org/10.1016/j.procs.2017.1 1.348.

Mohd, A., Rashid, R. A., Abdul Hamid, A. H. F., Sarijari, M. A., Rahim, M. R. B. A., Sayuti, H., \& Abdul Rashid, M. R. (2019). Development of android-based apps for courier service management. Indonesian Journal of Electrical Engineering and Computer Science, I5(2), I0271036. https://doi.org/I0.II59I/ijeecs.vI5.i2.ppI027-1036.

Musyaffi, A. M., Agustin, D., Sari, P., \& Respati, D. K. (202I). Understanding of digital payment usage during covid-19 pandemic: A study of UTAUT extension model in Indonesia. Journal of Asian Finance, Economics and Business, 8(6), 475-482. https://doi.org/10.13 I06/jafeb.202I.vol8.no6.0475.

Oxford Business Group. (2020). E-commerce provides economic boost for Indonesia as shoppers migrate online during the Covid-19 pandemic | Indonesia 2020 | Oxford Business Group. Retrieved from https://oxfordbusinessgroup.com/news/e-commerceprovides-economic-boost-indonesia-shoppers-migrate-online-during-covid-19-pandemic

Park, M., \& Lee, J. (202I). Investigation of college students' intention to accept online education services : An application of the UTAUT model in Korea. Journal of Asian Finance, Economics and Business, 8(6), 327-336. https://doi.org// 0.13 I06/jafeb.202I.vol8.no6.0327.

Singh, S., Kumar, R., Panchal, R., \& Tiwari, M. K. (2020). Impact of COVID-I9 on logistics systems and disruptions in food supply chain. International Journal of Production Research, 0(0), I-I6. https://doi.org/I0.1080/00207543.2020.1792000.

Smith, P. H., \& Branscum, P. W. (2020). Feasibility, utility, and limitations of a rapid community behavioral diagnosis for social distancing during the 2020 coronavirus pandemic. American Journal of Health Promotion. https://doi.org/ I0.I I77/0890 I I 7 I 20932460.

Stošić-Mihajlović, L., \& Trajković, S. (2020). The importance of logistics and supply chains for pandemia conditions. Journal of Process Management. New Technologies, 8(2), 53-59. https://doi.org// 0.5937/jouproman8-26138.

Tarhini, A., El-Masri, M., Ali, M., \& Serrano, A. (20I6). Extending the UTAUT model to understand the customers' acceptance and use of internet banking in Lebanon a structural equation modeling approach. Information Technology and People, 29(4), 830849. https://doi.org/I0.1 I08/ITP-02-2014-0034.

Tiongson, J. (20I5). App insights: How consumers use apps - Think with Google. Retrieved from Think with Google website: https://www.thinkwithgoogle.com/marketingstrategies/app-and-mobile/mobile-app-marketing-insights/

Tommasetti, A., Singer, P., Troisi, O., \& Maione, G. (2018). Extended theory of planned behavior (ETPB): Investigating customers' perception of restaurants' sustainability by 
testing a structural equation model. Sustainability (Switzerland), 10(7), I-2I. https://doi.org// 0.3390/sul 0072580.

Venkatesh, V., Morris, M. G., Davis, G. B., \& Davis, F. D. (2003). User acceptance of information technology: Toward a unified view. MIS Quarterly: Management Information Systems, 27(3), 425-478. https://doi.org/10.2307/30036540.

Venkatesh, V., Thong, J. Y. L., \& Xu, X. (2016). Unified theory of acceptance and use of technology: A synthesis and the road ahead. Journal of the Association for Information Systems, I 7(5), 328-376. https://doi.org/I0.I7705/I jais.00428.

Wang, G., Zhang, H., \& Zhang, J. (2019). On-Demand ride-matching in a spatial model with abandonment and cancellation. SSRN Electronic Journal, I-40. https://doi.org//0.2139/ssrn.34I47/6.

Wang, Xiaolei, Liu, W., Yang, H., Wang, D., \& Ye, J. (2018). Customer behavioural modelling of order cancellation in coupled ride-sourcing and taxi markets. Transportation Research Procedia, 38, 853-873. https://doi.org/10.1016/j.trpro.2019.05.044.

Wang, Xin, \& Huang, G. Q. (202I). When and how to share first-mile parcel collection service. European Journal of Operational Research, 288(I), I53-169. https://doi.org// 0.1016/j.ejor.2020.05.049.

WHO. (2020). Advice for the public. Retrieved November 4, 2020, from World Health Organization website: https:/www.who.int/emergencies/diseases/novel-coronavirus2019/advice-for-public. 